\title{
Detection of Brucellosis by Serological Techniques in Bovines
}

\author{
Tejal Walunj $^{1 *}$, Prashant Mhase ${ }^{1}$, Sujata Bhave², Dushyant Muglikar ${ }^{1}$ \\ and Mrunalini Pawde ${ }^{1}$ \\ ${ }^{1}$ Department of Veterinary Microbiology, ${ }^{2}$ Department of Veterinary Public Health, \\ KNP College of Veterinary Science, \\ Shirwal, Satara, India \\ *Corresponding author
}

\begin{abstract}
A B S T R A C T
Keywords

Brucellosis, Rose bengal plate test, ELISA, Cattle, buffalo

Article Info

Accepted:

18 January 2019

Available Online:

10 February 2019

Brucellosis is an important infectious disease of livestock affecting a wide range of animal species including human and is characterized by abortions, fetal death, reproductive tract complications and arthritis in animals with great losses. Early precise diagnosis with more sensitive and specific test is a very important for its control and eradication. For the diagnosis of brucellosis different serological tests are used widely, but often they come with certain disadvantages like longevity and lack specificity and gold standard isolation cultural test requires special biosecurity facilities and poses a danger of infection. Hence, highly sensitive genus specific molecular techniques are preferred. Hence present study deals with the screening of farms having clinical brucellosis with serological tests; RBPT and iELISA. It was concluded that brucellosis was more in animals belonging to Ahmednagar than Pune, was higher in buffaloes than in cattle, and was more in the aborted than In-contact animals and higher in animals of organized farms than unorganized farms. The seropositivity was marginally higher in ELISA-2 kit than Indigenous ELISA-1 followed by RBPT.
\end{abstract}

\section{Introduction}

Brucellosis is a highly contagious bacterial disease of zoonotic importance, causing significant reproductive losses in animals. The disease is caused by gram negative facultative intracellular non-sporeforming, minute coccobacilli of the genus Brucella. The organisms are known to be pathogenic for a wide variety of animals and human beings. Different species like $B$. abortus, $B$. melitensis, $B$. suis, B. ovis, B. canis, $B$. neotome and $B$. microti have been recognized as the specific causative agents of the disease in the different hosts. The first three species are the most significant, and within these species there are number of biovars (Verger et al., 1987; Scholz et al., 2008). The species $B$. ceti has been isolated and described, usually from dolphins, and B. pinnipedialis from seals (Foster et al., 2007). B. inopinata has been isolated from infected breast implants in women with clinical signs of brucellosis (Scholz et al., 2010). 
Brucellosis is considered one of the most dangerous zoonoses, and humans are most often infected with the species $B$. melitensis, less often with $B$. abortus and $B$. suis, and rarely with the species $B$. canis, though the species $B$. ceti and $B$. pinnipedialis can also rarely cause human disease (Sohn et al., 2003, Mcdonald et al., 2006). Occupational infections occur to butchers, milkman, laboratory staff, veterinarians, farmers, cattle breeders etc. Bovine brucellosis is distributed worldwide and it continues to be endemic in most parts of the world especially the developing countries (Trujillo et al., 1994), Mediterranean countries (Godfroid and Kasbohrer, 2002), and central Asia (Pappas et al., 2006). In India, brucellos is first recognized in 1942 and is now found in an endemic proportion throughout the country. It is reported to be on the increasing side in recent times due to increased trade and allover rapid movement of livestock (Renukaradhya et al., 2002).

Brucellosis has been known to cause enormous economic losses to the livestock industry by way of reducing the productive and reproductive potential of the affected animal due to the loss of calves, wool, meat and milk production, sterility, infertility as well as reduction or complete loss of milk yield after abortion (Chahotal et al., 2003). Brucellosis in livestock is responsible for a median loss of US $\$ 3.4$ billion (5th-95th percentile 2.8-4.2billion) as estimated by Singh et al., (2015). This disease in cattle and buffalo was accounted for 95.60 percent of the total losses occurring due to brucellosis in livestock populations in India. Singh et al., (2002) has reported annual economic losses to the tune of Rs. 350 million due to this disease. Kollannur et al., (2007) estimated that, in India there is loss of US\$ 58.8 million per year due to Brucellosis.

Good levels of antibodies are secreted in blood though out incubation phase and pathogenesis of organism the disease can be easily detected by applying indirect serological test. Conventionally, serological tests have been extensively used to screen for, or to confirm the disease. The routinely used serological tests for diagnosis of brucellosis in animals are Rose Bengal Plate Test (RBPT), Standard Tube Agglutination Test (STAT) and Enzyme Linked Immunosorbent Assay (ELISA). All tests are lightly sensitive and some of them are very specific. It is obvious from the available literature that no single serological test is free from demerits. This has prompted many workers to carry out studies on comparative efficacy of different serological tests in diagnosis of brucellosis. Nielsen (2002) and Gall and Nielsen (2004) after reviewing literature on various serological tests, concluded that no individual test was perfect; however, error could be minimized using the most reliable test. In general, ELISA is most sensitive, specific, reliable, and cost effective and can be employed for mass screening for brucellosis in livestock and human beings (Renukaradhya et al., 2002; Agasthya et al., 2007). The indirect ELISA (iELISA) has proved to be a highly sensitive test but sometimes may not be capable of differentiating between antibodies resulting from S19 vaccination, other false positive serological reactions (FPSR) and those induced by pathogenic Brucella strains. The iELISA therefore, is suggested to be more of a screening test rather than confirmatory test for testing of vaccinated cattle or herds affected by FPSR problems (OIE, 2004).

Brucellosis is endemic in the animals belonging to the dairy rich belt of the western region of Maharashtra. The work done in this region for detection of brucellosis is necessary for application of proper control and eradication of the disease in present situation. Also evaluation of the different tests for screening of brucellosis is important as 
diagnosis is the backbone of any disease eradication programme. Therefore, the present research was planned to diagnose the Brucellosis in animals using different serological tests.

\section{Materials and Methods}

\section{Collection of specimens}

\section{Whole blood in EDTA}

Blood samples were collected aseptically from the animals under investigation by jugular vein puncture using vaccutainer containing EDTA $-2 \mathrm{~K}$ and transported to the laboratory on ice and preserved at $-20^{\circ} \mathrm{C}$ till further processing. Around $5 \mathrm{ml}$ of whole blood was collected from each animal which subsequently was used for direct isolation of DNA.

\section{Serum samples}

For obtaining sera, blood samples were collected in vaccutainer without anticoagulant and kept in an upright position at room temperature for about $2 \mathrm{~h}$. The serum was separated in sterile screw capped plastic vials and stored at $-20^{\circ} \mathrm{C}$ till further use.

\section{Serological tests}

\section{Rose Bengal Plate Test (RBPT)}

The coloured antigen required for RBPT was obtained from the Division of Biological products, Indian Veterinary Research Institute, Izatnagar, Uttar Pradesh and the test was performed as per the standard protocol of agglutination test. Briefly, a drop of serum $(30 \mu \mathrm{l})$ was placed on clean grease free glass slide and an equal quantity of antigen was added and mixed thoroughly with the help of inoculation loop. The mixture was observed for clumping / agglutination for one min. and the results were recorded as agglutination $(+)$ and no agglutination (-).

\section{Enzyme-linked immunosorbent assay (IgG ELISA)}

ELISA is an antigen antibody reaction assay. ELISAs are typically performed in 96 well polystyrene plates. Antigens are attached to the surface. Further specific antibody from the sample is applied over the surface so it can bind to the antigen. This antibody is linked to an enzyme, and, in the final step, a substance containing the enzyme's substrate is added. The subsequent reaction produces a detectable signal, most commonly a color change in the substrate. For the present study precoated ELISA plate and all reagents used were gifted by Department of Veterinary Public Health, Nagpur Veterinary College, Nagpur.

\section{Enzyme-linked immunosorbent assay (IDVet ELISA)}

The commercial ELISA kit (IDvet kit) was used during present studies for processing the same samples for Brucellosis. All reagents were allowed to come to room temperature $\left(21^{\circ} \mathrm{c} \pm 5^{\circ} \mathrm{C}\right)$ before use. All reagents were homogenized by inversion. The protocol given by the manufacturer was followed to perform ELISA.

Interpretation of iELISA: For each sample, the S/P Percentage was calculated as follows using the sample and control values:

$\mathrm{S} / \mathrm{P}=\mathrm{O} . \mathrm{D}$. of sample - O.D. of NC

O.D. of PC - O.D. of NC

Where - NC-Negative control

PC- Positive control

\section{Results and Discussion}

The present studies were planned for detection of Brucellosis in cattle and buffalo 
by serological and molecular techniques in the suspected animals at selected locations in Pune and Ahmednagar in Western region of Maharashtra state. Animals belonged to the organized and unorganized farms and samples were collected from aborted and 'In-contact' animals. Simultaneously as per OIE,(2016) recommendations more than two serological tests were employed and these tests were evaluated against molecular detection method for detection of brucellosis in the blood and serum samples of the animals. The tests employed for detection of brucellosis were RBPT for screening of animals followed by iELISA for detection of antibodies and genus specific PCR on the samples collected for diagnosis of brucellosis. A total of 401 animals including cattle $(n=171)$, buffaloes $(n=230)$ were studied considering the following parameters:

Collection of sera and whole blood samples and screening for anti-Brucella antibodies in the sera by RBPT.

Detection of anti-Brucella antibodies in the sera by i-ELISA (IgG ELISA kit and IDVet ELISA Kit).

\section{Rose Bengal Plate Test (RBPT)}

The results of screening of cattle $(n=171)$ for brucellosis at Pune and Ahmednagar region belonging to organized and unorganized farms were as per the table 1. Out of total 103 sample screened with RBPT from Pune region $05(47.66 \%)$ were found positive amongst 12 aborted cattle of organized farms, while $04(44.44 \%)$ were found positive amongst 09 aborted cattle of unorganized farms. Whereas, $10(21.33 \%)$ were positive amongst 46 'In-contact' cattle of organized farms, and 09(25.00\%) were found positive amongst 36 'In-contact' cattle of unorganized farms. Out of total 68 cattle samples screened with 36 RBPT from Ahmednagar region,
07(43.75\%) were found positive amongst 16 aborted cattle of organized farms and $03(60.00 \%)$ were found positive amongst 05 aborted cattle of unorganized farms while, 09(31.03\%) were found positive amongst 29 'In-contact' cattle of organized farms and 06(33.33\%) were found positive amongst 18 'In-contact' cattle of unorganized farms. In all cattle, $15 / 58(25.86 \%)$ of organized farm and $13 / 45(28.88 \%)$ of unorganized farm totaling $28(27.18 \%)$ cattle from Pune region reacted positive with RBPT, while results from Ahmednagar of total cattle indicated 16/45 $(35.55 \%)$ of organized farm, 09/23 (39.13\%) from unorganized farm with total $25(36.76 \%)$ of cattle reacted positive with RBPT. Thus, from total cattle screened with RBPT, 31/103 $(30.09 \%)$ from organized farms, 22/68 $(32.35 \%)$ of unorganized farms, totaling to overall $53(30.99 \%)$ cattle as positive reactants.

The result of screening of Buffaloes $(n=230)$ for brucellosis in Pune and Ahmednagar region collected from organized and unorganized farms were as depicted. Out of total 42 samples screened with RBPT from Pune region 04(66.66\%) were found positive amongst 06 aborted buffaloes of organized farms and 02(66.66\%) were found positive out of 03 aborted buffaloes of unorganized farms while, $05(25.00 \%)$ were found positive amongst 20 'In-contact' buffaloes of organized farms, and 04(30.76\%) buffaloes were found positive out of 13 'In-contact' buffaloes of unorganized farms. Out of total 188 buffalo samples screened with RBPT from Ahmednagar region, 11(31.42\%) were found positive amongst 35 aborted buffaloes of organized farms and 08/20 (40.00\%) were found positive thus, 19/55 (34.54\%) were positive amongst aborted buffaloes. Whereas, $39 / 46(44.82 \%)$ buffaloes of organized farm and 20/46(43.47\%) from unorganized farms reacted positive, thus 59/133 (44.36\%) 'Incontact' buffaloes of Ahmednagar were 
RBPT positive. So 50/122 (40.98\%) total buffaloes of organized farms, 28/66(42.42\%) of unorganized farms, thus total $78 / 188(41.48 \%)$ buffaloes of Ahmednagar reacted RBPT positive. Overall 148 samples from organized farms screened with RBPT reveled 59(39.86\%) positive animals, while out of 82 animals screened from unorganized farm $34(41.66 \%)$ were found positive with RBPT, thus total 93(40.08\%) buffaloes screened reacted RBPT positive out of total 230 animals.

\section{Enzyme Linked Immuno Sorbent Assay (IgG ELISA)}

Proportionately selected two hundred serum samples consisting equal number of cattle and buffaloes $(n=100$ each) were screened with iELISA kit procured from Department of VPH, Nagpur Veterinary College, and the results of screening of cattle for brucellosis in Pune and Ahmednagar region collected from organized and unorganized farms. Fifty cattle samples screened with IgG ELISA from Pune region resulted in 04/06 (66.66\%) positive aborted cattle of organized farms while 04/05 $(80.00 \%)$ positive cattle amongst aborted cattle of unorganized farms. While 08/23 (34.78\%) were found positive amongst 'Incontact' cattle of organized farms and 05/16 $(31.25 \%)$ were observed positive amongst 'In-contact' cattle of unorganized farms. The cattle samples $(n=50)$ screened with $\mathrm{IgG}$ ELISA from Ahmednagar region 07/12 $(58.33 \%)$ were found positive amongst aborted cattle of organized farms and 01/03 $(33.33 \%)$ were found positive amongst aborted cattle of unorganized farms, thus total 08/15(53.33\%) cattle resulted positive from aborted animals of Ahmednagar. Whereas, 09/20 (45.00\%) 'In-contact' cattle of organized farms and $05 / 15(33.33 \%)$ of unorganized farms of unorganized farms $5(33.33 \%)$ were found positive, thus total $14(40.00 \%)$ 'In-contact' cattle from
Ahmednagar resulted ELISA positive. Overall cattle were screened with IgG ELISA indicated 28/61 (45.90\%) cattle positive from organized farm and 15 (38.46\%) from unorganized farms with overall positivity with IgG ELISA in $43(43.00 \%)$ cattle as positive out of 100 animals.

The result of screening of Buffaloes $(n=100)$ for brucellosis in Pune and Ahmednagar region collected from organized and unorganized farms. Out of total 40 sample screened with IgG ELISA from Pune region 04/06 $(66.66 \%)$ were found positive amongst aborted buffaloes of organized farms and 02/03 (66.66\%) were found positive were amongst aborted buffaloes of unorganized farms thus, total $06 / 09(66.66 \%)$ aborted buffaloes were positive. While 07/20(35.00\%) were found positive amongst 'In-contact' buffaloes of organized farms and 05/11 (25.00\%) amongst 'In-contact' buffaloes of unorganized farms were detected positive, thus, 12/31(38.07\%) 'In-contact' buffaloes were found positive.

Out of total 60 samples screened with $\operatorname{IgG}$ ELISA from Ahmednagar region, 08/12(66.66\%) aborted buffaloes were found positive from organized farm and 04/06 (66.66\%) were found positive, thus 12/18 $(66.66 \%)$ from aborted buffaloes of unorganized farms were positive. In the 'Incontact' buffaloes, 11/27(40.70\%) were found positive belonging to organized farms and 06/15 (40.00\%) were found positive amongst buffaloes of unorganized farms, thus, 17/42 $(39.53 \%)$ buffaloes were positive from Ahmednagar. Overall 65 sample from organized farms screen with IgG ELISA reveled $30(46.15 \%)$ buffaloes positive, while out of 35animals screened from unorganized farm $17(48.57 \%)$ were found positive with IgG ELISA, thus total $47(47.00 \%)$ animal were found positive out of 100 buffaloes. 


\section{Enzyme Linked Immuno Sorbent Assay (ID vet ELISA kit)}

For the screening of Brucellosis serum samples selected as above in table 5 were also processed with IDVet ELISA kit for assessment of their efficacy and the results of screening of cattle $(n=100)$ for brucellosis in Pune and Ahmednagar region collected from organized and unorganized farms. Out of total 50 sample screened with IDvet ELISA from Pune region 05/06 (83.33\%) were found positive amongst aborted cattle of organized farms and 04/05 (80.00\%) were found positive amongst aborted cattle of unorganized farms while, 09/23 (39.13\%) were found positive amongst 'Incontact' cattle of organized farms and 06/16 (37.50\%) were found positive amongst 'In-contact' cattle of unorganized farms. Out of total 50 sample screened with IDvetELISA from Ahmednagar region 10/12 (83.33\%) were found positive were from aborted cattle of organized farms while, 01/03 (33.33\%) were found positive in aborted cattle of unorganized farms, thus, 11/15 (73.33\%) aborted animals were Brucella positive. In the samples of 'In-contact' animals of Ahmednagar, 09/20(45.00\%) were cattle of organized farms and 05/15 (33.33\%) were found positive amongst cattle of unorganized farms thus, $14 / 35(40.00 \%)$ cattle from Ahmednagar region were detected serologically positive. Overall 61 sample from organized farm screen with RBPT reveled $33(54.09 \%)$ positive cattle, while out of 39 animals screened from unorganized farms, $16(41.02 \%)$ were found positive with IDvetELISA, thus total $49(49.00 \%)$ cattle were detected positive out of 100 animals screened with IDVet ELISA.

The result of screening of Buffalo $(\mathrm{n}=100)$ for brucellosis with IDVet ELISA from Pune and Ahmednagar region collected from unorganized and organized farms were analyzed. Out of total 40 buffalo sera samples screened with this ELISA from Pune region resulted in 03/06 (50.00\%)samples positive amongst aborted buffaloes belonged to organized farms, while,02/03(66.66\%) were found positive thus, 05/09 (55.55\%) aborted buffaloes of unorganized farms were detected ELISA positive. Whereas, from the 'Incontact' buffaloes 09/20 (45.00\%) were found positive in organized farms and05/11(41.45\%) amongst unorganized farm, totaling 14/31 (45.16\%) 'In-contact' buffaloes were detected positive. Out of total 60 samples screened with IDvetELISA from Ahmednagar region, 10/12(83.33\%) aborted buffalo of organized farms were positive while 04/06(66.66\%) aborted were found positive of unorganized farms, thus, total $14 / 18(77.77 \%)$ aborted buffaloes were detected positive, and10/27 (37.03\%) of 'Incontact' buffaloes of organized farms and $06(40.00 \%)$ 'Incontact' buffaloes of unorganized farms were diagnosed positive, thus total20/39(68.00\%) from organized farm, $10 / 21(47.61 \%)$ from unorganized farm and total $30 / 60 \quad(50.00 \%)$ buffaloes from Ahmednagar region had Brucellos is serologically. Overall 65 sample from organized farms when screened with IDvet ELISA revealed 32(49.23\%) positive animal while out of 35 animals screened from unorganized farm 17(48.57\%) were found positive with IDvet ELISA thus, total49(49.00\%) buffaloes overall were found positive serologically for Brucellosis.

\section{Comparison of results of serological tests}

The serological test (RBPT, IgG ELISA, and IDvet ELISA) performed for screenings of brucellosis in the suspected animals were evaluated and their efficiency was analyzed.

The cattle sera samples were tested by RBPT, IgG ELISA, and IDVet ELISA resulted in 53/171(30.99\%), 43/100 (43.00\%) and 49/100 $(49.00 \%)$ positivity, respectively which sera samples of buffaloes revealed positive results 
in93/230 (40.43\%), 47/100(47.00\%) and $49 / 100(49.00 \%)$, respectively, Thus overall sera samples when processed with different tests detected 146/401(36.40\%) by RBPT, 90/200 (45.00\%) by IgG ELISA and 98/200 $(49.00 \%)$ samples positive for brucellosis.

Table.1 Overall results of different serological tests for detection of brucellosis in cattle and buffaloes

\begin{tabular}{|c|c|c|c|c|c|c|c|}
\hline \multirow[t]{2}{*}{ District/region } & \multirow{2}{*}{$\begin{array}{c}\text { Animals } \\
\text { tested }\end{array}$} & \multicolumn{2}{|c|}{ RBPT } & \multicolumn{2}{|c|}{ IgG ELISA } & \multicolumn{2}{|c|}{ IDvet ELISA } \\
\hline & & Samples & Positive & Samples & Positive & Samples & Positive \\
\hline Pune & Cattle & $103^{\circ}$ & $28(27.18)$ & 50 & $21(42.00)$ & 50 & $24(48.00)$ \\
\hline Ahmednagar & & 68 & $25(36.76)$ & 50 & $22(44.00)$ & 50 & $25(50.00)$ \\
\hline Total & & 171 & $53(30.99)$ & 100 & $43(43.00)$ & 100 & $49(49.00)$ \\
\hline Pune & Buffalo & 42 & $15(35.71)$ & 40 & $18(45.00)$ & 40 & $19(47.50)$ \\
\hline Ahmednagar & & 188 & $78(41.48)$ & 60 & $29(48.33)$ & 60 & $30(50.00)$ \\
\hline Total & & 230 & $93(40.08)$ & 100 & $47(47.00)$ & 100 & $49(49.00)$ \\
\hline Grand Total & & 401 & $\begin{array}{l}146 \\
(36.40)\end{array}$ & 200 & $90(45.00)$ & 200 & $98(49.00)$ \\
\hline
\end{tabular}

Brucellosis has recently been identified as one of the greatest problems in cattle and buffaloes in India and this infection is consistently found on the rise. There are various reasons behind this problem like the unavailability of testing facilities in the field, lack of awareness and ignorance of animal owners and socio-economic and religious beliefs. For the success of eradication program it is necessary to diagnose the disease precisely. For the diagnosis of disease it is necessary to have the easy, robust, sensitive and specific test so as to take the appropriate control measures to prevent the further spread of infection.

Therefore, present studies were focused on testing the cattle and buffalo herds reared in organized and unorganized farms in dairy rich belt of western Maharashtra where the recent history of abortions in last trimester and retained placenta were reported. For screening of Brucellosis various serological and molecular techniques are implemented successfully. The gold standard method still recommended is isolation of Brucella organisms from the infected animals. But it is time-and resource-intensive and it requires level 3biocontainment facilities and highly skilled technical personnel to handle samples and live bacteria for eventual identification and biotyping. The serological tests facilitate relatively quick and without much more risk of laboratory acquired infection for diagnosis of brucellosis. However, the major disadvantage of serological tests is the lack of adequate specificity.

The present investigation therefore was taken up with an intention of studying the positivity of animals in the Brucella infected farms and to evaluate different screening techniques in detection of bovine brucellosis. A total of 401 serum and 24 blood samples of animals were tested for the studies from farm shaving the clinical history of abortions associated with Brucella infection.

\section{Serological tests}

As per OIE guidelines (2016) for diagnosis of brucellosis more than two serological tests simultaneously are recommended to rule out the false results. On the Basis of an extensive 
work done on serological tests it has been reported that no individual test is perfect for diagnosis of brucellosis; however the error could be minimized using the most reliable test (Nielsen, 2002; Gall and Nielsen,2004). It is generally considered that a positive response in the agglutination test, which detects mainly $\operatorname{IgM}$, is not indicative of brucellosis if the result is not further confirmed by a positive IgG response (Bhanu Rekha et al., 2013). Hence, in the present research two serological screening tests were employed for detecting $\operatorname{IgM}$ and $\operatorname{IgG} 1$ Brucella antibodies in cattle and buffaloes with RBPT and commercial IDvet ELISA Kit. Also the 'In house' developed iELISA kit supplied by ICAR funded project niche Area of Excellence Project on "Centre for Zoonoses" at the Department of Veterinary Public Health, Nagpur Veterinary College, Nagpur was employed for diagnosis of Brucellosis.

\section{RBPT}

For diagnosis of brucellosis several serological tests have been widely employed and many researchers have evaluated their sensitivity, specificity and efficacy in detection of brucellosis (Vizcaino and Fernandez-Lago, 1992). In present studies the sero positivity with RBPT of sera screened from animals of organized farms of Pune region comprising of aborted and 'In-contact' animals indicated obvious higher positivity of $50.00 \%$ in the former than later $22.72 \%$ as well as in the unorganized farms of this region same higher values of $66.66 \%$ in aborted and $26.50 \%$ in 'In-contact' animals was observed, respectively. In organized farms animals sero-positivity was noted in $28.57 \%$ which was less than in $31.14 \%$ in unorganized dairy farms. The higher seropositivity was observed in buffaloes $(35.71 \%)$ than that of cows $(27.18 \%)$ possibly may be attributed to the natural service used in buffaloes (Chakraborty et al., 2000; Chauhan et al., 2000). Almost same results were reported from Ahmednagar region indicating high sero-positivity in $41.48 \%$ samples from buffaloes than $36.76 \%$ cattle. Lower percent of aborted animals $38.15 \%$ were detected positive than that of $41.11 \%$ 'In-contact' animals, respectively. Also lower percentage of animals from organized farms $39.52 \%$ were found positive than that of $41.57 \%$ of unorganized farm animals.

\section{Detection of brucellosis with iELISA}

The sero-positivity with IgG ELISA of sera screened from animals of organized farms of Pune region comprising of aborted and 'Incontact' animals indicated obvious higher positivity of $66.66 \%$ in the former than later $45.45 \%$ as well as unorganized farms of this region reported same higher values of $75.00 \%$ and lower in aborted and $37.03 \%$ in 'in-contact' animals, respectively. In organized farms animals were noted in $35.38 \%$ than in $45.71 \%$ in unorganized dairy farms. The higher sero-positivity was observed in buffaloes $(45.00 \%)$ than that of cows $(42.00 \%)$ possibly may be attributed to the natural service used in buffaloes. Almost same results were reported from Ahmednagar region indicating high sero-positivity in $48.33 \%$ samples from buffaloes than $44.00 \%$ cattle. Higher percent of aborted animals $60.60 \%$ were detected positive than that of $40.25 \%$ 'In-contact' animals, respectively. Also higher percentage of animals from organized farms $57.37 \%$ were found positive than that of $41.02 \%$ of unorganized farm animals.

The sero-positivity with IDvet kit ELISA of sera screened from animals of organized farms of Pune region comprising of aborted and 'In-contact' animals indicated obvious higher positivity of $66.66 \%$ in the former than later $41.86 \%$ as well as unorganized farms of this region reported same higher values of $75.00 \%$ in aborted and $40.74 \%$ in 'In-contact' 
animals, respectively. In organized farms animals was noted in $40.00 \%$ than in $48.57 \%$ in unorganized dairy farms. The higher seropositivity was observed in buffaloes $(47.50 \%)$ than that of cows $(48.00 \%)$ possibly may be attributed to the natural service used in buffaloes. Concurrent findings have been reported earlier (Chakroborty et al., 2000; Chauhan et al., 2000). Similar results were observed from Ahmednagar region indicating same sero-positivity in 50\% samples from buffaloes and cattle. Higher percent of aborted animals (78.78\%) were detected positive than that of $38.96 \%$ 'In-contact' animals, respectively. Also higher percentage of animals from organized farms $63.93 \%$ were found positive than that of $41.02 \%$ of unorganized farm animals.

The positivity of brucellosis in unorganized farms was noticed less compared to organized farms in our studies which could beat tributed to the break in chain of disease spread among unorganized discrete populations. The high prevalence rate of brucellosis in buffaloes compared to cattle was recorded could be due to the use of infected buffalo bulls in natural service and rare use of artificial insemination in the farms. Our findings were recorded in consistence with Ramesh et al., (2013). Our outcome of research was in close accordance with that reported earlier by other researchers (Chakroborty et al., 2000; Chauhan et al., 2000). Our findings also correlated with Bhanu Rekaha (2013) revealing higher prevalence of bovine brucellosis in organized farms as compared to unorganized farms, which is due to spread of infection from one animal to other by contact between the females or during natural service with infected bull.

\section{Comparison of serological tests}

In case of serological tests, there are a number of different methodologies available for diagnosis (Godfroid et al., 2010) out of which RBPT and iELISA were employed for detection of $\mathrm{IgG}$ antibodies in suspected animals for brucellosis. Highly sensitive and specific diagnostic test like ELISA helps in screening of bovine brucellosis at the low titer compared to RBPT, STAT and other diagnostic tests BhanuRekaha. (2013). In present studies samples collected from cattle were screened with RBPT had revealed 30.99\% seropositivity, while with IgG ELISA it was $43.00 \%$ and in IDVet ELISA showed $49.00 \%$ samples sero-positive for Brucellosis, respectively. The results of seropositivity in samples collected from buffaloes with tests like RBPT showed the positive results in $40.08 \%$, while with IgG ELISA in $47.00 \%$, and that in IDVet ELISA showed $49.00 \%$ sero-positivity, respectively. Thus, the overall sero-positivity in the serum samples when screened with RBPT presented brucellosis antibodies in $36.40 \%$, with $\mathrm{IgG}$ ELISA in $45.00 \%$, and that in IDVet ELISA $49.00 \%$, respectively (Table 1). From these values the sero-positivity of IDvet Kit ELISA in detection of brucellosis in animals was found marginally higher than both $\mathrm{IgG}$ ELISA followed by RBPT. The findings in our study indicated markedly higher number of animals positive by both iELISA and RBPT than reported epidemiology in normal course. This may be due to selection of farms with recent clinical history of abortions indicating acute brucellosis in animals. The high sero-prevalence of brucellosis was recorded in our study, because the samples were collected at the phase of outbreak, when heard was showing the signs of abortions, retained placenta and infertility. These findings were in accordance with that recorded by Heck et al., (1980). The results of our study are in accordance with the findings of many other workers who found iELISA to be more sensitive than the RBPT (Londhe et al., 2009; Madale et al., 2011). 
In conclusion, both RBPT and iELISA are necessary to be performed together as screening tests.

\section{References}

Agasthya, A. S., Isloor. S. And Prabhudas, K. 2007. Brucellosis in high risk group individuals. Indian J. Med. Microbiol.25: 28-31.

Bhanu Rekha, V., Gunaseelan, L., Subramanian, A., and Yale, S. G. 2013. A study on bovine Brucellosis in an organized dairy farm. Vet. world, 6: 681- 685 .

Chahotal, Rajesh., Mandeep, Sharmal., Katochl, R. C., Subhash, Verma., Singh, M., Vipasha Kapoorl., and Asrani R.K. 2003. Brucellosis outbreak in an organized dairy farm involving cows and in contact human beings, in Himachal Pradesh, India. Veterinarski Aarhiv. 73: 95-102.

Chakraborty, M., Patgiri and Sarma, D.K. 2000.Use of Rose Bengal Plate Test, Serum Agglutination Test and Indirect-ELISA for detecting brucellosis in bovines. Indian $\mathbf{J}$. Comp. Microbiol. Immunol. Infect. Dis. 21: 24-25.

Chauhan, H. C., Chandel, B. S. And Shah, N. M. (2000) Seroprevalence of brucellosis in buffaloes in Gujarat. Indian Vet. J. 77: 1105-1106.

Gall, D. and Nielsen, K. 2004. Serological diagnosis of bovine brucellosis: a review of test performance and cost comparison. Rev. Sci. Tech. Off. Int. Epiz. 23: 989 - 1002.

Godfroid, J. and Kasbohrer, A. 2002. Brucellosis in the European Union and Norway at the turn of the twenty-first century. Vet. Microbiol. 90: 135-14.

Godfroid, J., Nielsen K. and Saegerman C. 2010.Diagnosis of brucellosis in livestock and wildlife. Croat. Med. J.
51: 296-305.

Heck, F., Williams J. and Pruett, J. 1980. Interpretation of spectrophotometric absorbance values to define result of enzyme linked immunosorbant assay. J. Clin. Microbiol. 11:396-401.

Kollannur J.D, Rathore R. and Chauhan R.S. 2007.Epidemiology and economics of brucellosis in animals and its zoonotic significance. ISAH-2007 Tartu, Estonia, 466-468.

Londhe S. P., Aher A. S., Jagadale S. D., Dighe S. D., Bannalikar A.S. 2014. Evaluation of BCSP $31 \mathrm{kda}$ and IS711 PCR assays in detection of bovine brucellosis. Indian J. Vet. Res. 22(1): $8-14$.

Madale D.S. (2011) Detection of Brucella spp. In animals by conventional and molecular techniques. M.V.Sc. Thesis submitted to Maharashtra Animal and Fisheries Science University, Nagpur.

Mcdonald, W. L., Jamaludin. R., Mackereth. G., Hansen, M., Humphrey, S., Short, P., Taylor, T., Swingler, J., Dawson, C.E., Whatmore, A.W., Stubberfield, E., Perrett, L. L. and Simmons, G. 2006. Isolation from a Patient with Spinal osteomyelitis in New Zealand. J. Clin. Microbiol. 76:122-124.

Nielsen, K. 2002. Diagnosis of brucellosis by serology. Vet. Microbiol. 90: 447- 459

OIE. (2004) Bovine brucellosis, chapter 2.3.1 manual of standard for diagnostic test and vaccines, 5th edition OIE. Paris on 16 march 2006, Paris. OIE. (2016) Manual of Dignostic Test and Vaccine for Terristial Animals.

Pappas, G., Papadimitriou, P., Akritidis. N., Christou L. and Tsianos, E.V. 2006. The new global map of human brucellosis. Lancet Infect. Dis. 6:9199.

Ramesh V., Jagapur. Rathore. Rajesh., Karthik. K., and Ramesh S. 2013. Seroprevalence studies of bovine 
brucellosis using indirect enzymelinked immunosorbent assay (IELISA) at organized and unorganized farms in three different states of India. Vet. World, pp. 550-553.

Renukaradhya, G.J., Isloor, S. and Rajsekhar. M. 2002. Epidemiology, zoonotic aspect, vaccination and control / eradication of Brucellosis in India. Vet. Microbiol. 90:183-195.

Scholz H. C., Hubalek. Z., Sedlacek. I., Vergnaud. G., Tomaso. H., Al Dahouk. S., et al., 2008. Brucella microti. Nov., isolated from the common vole Microtus arvalis. Int. J. Syst. Evol. Microbiol. 58(2): 375-382.

Scholz, H. C., Nockler, K., Llner, C. G. et al., 2010. Brucella inopinata sp. nov., isolated from a breast implant infection. Int. J. Sys. Evol. Microbiol. 60(4): 801-808, 2010.

Singh S.P., Kumar, S., and Kumar, A. 2002. Advance in veterinary public health. First annual conference IAVPH held at Pantnagar.

Singh, B. B., Dhand, N. K., Gill, J. P. S. 2015.
Economic losses occurring due to the brucellosis in Indian livestock population. Prevet. med. 119(34):211-5.

Sohn, A. H., Probert W. S., Glaser C. A., Gupta N., Bollen A. W., Wong J. D., Grace E. M. and McDonald, W. C. 2003. Human neurobrucellosis with intracerebral granuloma caused by a marine mammal Brucella spp. Emerg. Infect. Dis. 9: 485-488.

Trujillo, I.Z., Zawala, A.N., Caceres, J.G. and Miranda, C.Q. 1994. Brucellosis Infection. Infect. Dis. Clin. North America. 8: 225-241.

Verger, J. M., Grimont, F., Grimont, P. D.A and Grayon, M. 1987.Taxonomy of the genus Brucella. Ann. Inst. Pasteur Microbiol. 138: 235-238.

Vizcaino, N., and Fernandez-Lago, L. 1992.A rapid and sensitive method for the identification of Brucella species with a monoclonal antibody. Res. Microbiol. 143: 513-518.

\section{How to cite this article:}

Tejal Walunj, Prashant Mhase, Sujata Bhave, Dushyant Muglikar and Mrunalini Pawde. 2019. Detection of Brucellosis by Serological Techniques in Bovines. Int.J.Curr.Microbiol.App.Sci. 8(02): 2124-2134. doi: https://doi.org/10.20546/ijcmas.2019.802.246 